Tohoku J. exp. Med., 1982, 137, 369-377

\title{
Inhibitory Effect of Vitamin $E$ on Lipoperoxide Formation in Rat Adrenal Gland
}

\author{
Fumio Umeda, Ken-ichi Kato, Hiroshi Ibayashi, \\ Masaharu KoJima, * Yozaburo Shibata $\dagger$ and Torao \\ Yамамото $\dagger$ \\ The Third Department of Internal Medicine, Faculty of \\ Medicine, *Radiopharmaceutical Chemistry, Faculty of \\ Pharmaceutical Science and the First Department of Anatomy, \\ Faculty of Medicine, Kyushu University, Fukuoka 812
}

\begin{abstract}
Umeda, F., Kato, K., Ibayashi, H., Kojima, M., Shibata, Y. and Yamamoto, T. Inhibitory Effect of Vitamin E on Lipoperoxide Formation in Rat Adrenal Gland. Tohoku J. exp. Med., 1982, 137 (4), 369-377 — The tissue uptake of vitamin E administered to the rats was strikingly high in the adrenal glands, and microradioautographic studies showed that the vitamin was localized morphologically in the cells of fascicular and reticular zones of the adrenal cortex, where lipofuscin pigment appears with aging. On the other hand, it was confirmed that the TBA content in rat plasma and adrenal gland was elevated following whole-body ${ }^{60} \mathrm{Co}$ irradiation as an aging model. It was also demonstrated that the TBA content in rat adrenal markedly increased in conditions of vitamin $\mathrm{E}$ deficiency with and without irradiation. $\cdots$ vitamin E; lipoperoxide formation; rat adrenal gland
\end{abstract}

In 1956, Harman proposed the free radical theory of aging, suggesting that a free radical might play an important role in the natural aging process. On the other hand, it is well known that with aging a brown pigment called lipofuscin is morphologically observed to accumulate in the brain, liver, and adrenal gland cells. Einarson and Ringsted (1938) demonstrated that a similar pigment, which is today generally called ceroid, was observed in the tissues of vitamin $\mathrm{E}$ deficient animals. In a recent histochemical study by Hirai and Yoshikawa (1970), it was shown that these two pigments, lipofuscin and ceroid, were composed of similar polymers of lipoperoxide and denatured protein. It has been proposed that vitamin $\mathrm{E}$ which acts as an antioxidant can inhibit the formation of lipoperoxide in vivo. Therefore, the preventive effects of vitamin $\mathrm{E}$ can be expected on some aging phenomena (Zalkin and Tappel 1960; Tappel 1962, 1968; Tappel et al. 1973).

In the present study we examined that tissue uptake of vitamin $\mathrm{E}$ administered to the rats. Furthermore, the morphological localization of administered vitamin $\mathrm{E}$ in the rat adrenal gland was also studied by microautoradiography.

It is well known that $\mathrm{x}$-ray irradiation reduces the life span. This biological action is thought to be indirectly brought about by the free radicals. So far there

Received for publication, October 13, 1981. 
have been a number of reports on the enhancement of lipoperoxide formation resulting from x-ray irradiation (Horgan et al. 1957; Philpot and Roodyn 1959; Wyss et al. 1963). In the present experiments we could confirm the enhancement of lipoperoxide formation in vivo following whole-body gamma ray irradiation of ${ }^{60} \mathrm{Co}$ to rats. The inhibitory effect of antioxidant vitamin $\mathrm{E}$ on lipoperoxide formation in vivo, particularly in the irradiated and unirradiated adrenal glands, was studied.

\section{Materials and Methods}

Radiotagged compounds and other chemicals. D- $\alpha$-Tocopherol-5-methyl- ${ }^{3} \mathrm{H}$ with a specific radioactivity of $9.4 \mathrm{mCi} / \mathrm{mg}$ was commercially obtained from the Radiochemical Center, Amersham. The isotope was purified by thin layer chromatography before use. NRM2 emulsion was also commercially obtained from Sakura Co., Ltd., Tokyo. Other chemicals of special purity grades were obtained commercially.

Animals and diets. Male Wistar rats, four to five weeks old, were used in these experiments. The composition of the basal vitamin $\mathrm{E}$ deficient diet obtained from the Laboratory of Eisai Co., Ltd., Tokyo is shown in Table 1 (Masugi and Nakamura 1976). The control diet contained $2 \mathrm{mg}$ of $s$-tocopherol per $100 \mathrm{~g}$ of diet added into the basal vitamin E deficient diet.

Tissue uptake of radioactive vitamin $E$. Six normal rats weighing 130 to $140 \mathrm{~g}$, were fasted for $6 \mathrm{hr}$ prior to experiment. Then individual rats were given intraperitoneally radioactive tocopherol in a dose of about $330 \mu \mathrm{Ci}$ suspended in $0.3 \mathrm{ml}$ of $2 \%$ Tween 80 saline solution. Two animals were killed by decapitation at 12, 24, and $48 \mathrm{hr}$ following injection. The tissues from two animals were removed and cut at random into many tiny pieces and pooled together. Portions of the pooled pieces were weighed, packed with paper and oxidized with Packard Sample Oxidizer Type 300 . An aliquot $(1.0 \mathrm{ml})$ of blood was soaked in paper and oxidized. Radioactive oxidized $\mathrm{H}_{2} \mathrm{O}$ was placed in a counting vial and $10 \mathrm{ml}$ of toluene scintillator (PPO $4 \mathrm{~g}$ POPOP $0.1 \mathrm{~g}$ in 1 liter of toluene) was added. Tritium activity counting was done with Aloka Liquid Scintillation Counter Type 502. One of the four adrenals from two rats which were killed at the same time following injection was used for the microradioautographic study.

TaBle 1. Composition of basal vitamin $E$ deficient diet

$\begin{array}{lc}\quad \text { Nutrients } & \%(\mathrm{w} / \mathrm{w}) \\ \text { Cornstarch } & 38 \\ \text { Vitamin free casein } & 25 \\ \alpha \text {-Malt starch } & 10 \\ \text { Powered filter paper } & 8 \\ \text { Purified lard } & 6 \\ \text { Mineral mixture* } & 6 \\ \text { Granuled sugar } & 5 \\ \text { Vitamin mixture } \dagger & 2\end{array}$

* Mineral mixture contains K $692 \mathrm{mg}, \mathrm{P} 597 \mathrm{mg}$, Ca $411 \mathrm{mg}, \mathrm{Na}$ $270 \mathrm{mg}, \mathrm{Mg} 86 \mathrm{mg}, \mathrm{Fe} 41 \mathrm{mg}, \mathrm{Zn} 0.4 \mathrm{mg}$, Mn $1.3 \mathrm{mg}, \mathrm{Cu} 0.08 \mathrm{mg}$, and $\mathrm{I} 7.7 \mathrm{mg}$ per $100 \mathrm{~g}$ of diet. †Vitamin mixture contains vitamin A acetate 1,000 IU, vitamin $\mathrm{D}_{3} 200 \mathrm{IU}$, thiamine-HCl $2.4 \mathrm{mg}$, riboflavin $8.0 \mathrm{mg}$, pyridoxine- $\mathrm{HCl} 1.6 \mathrm{mg}$, cyanocobalamin $1.0 \mu \mathrm{g}$, L-ascorbic acid $60.0 \mathrm{mg}$, vitamin $\mathrm{K}_{3} 10.4 \mathrm{mg}$, D-biotin $0.04 \mathrm{mg}$, folic acid $0.4 \mathrm{mg}$, Ca-pantothenate $10.0 \mathrm{mg}, \mathrm{p}$-aminobenzoic acid $10.0 \mathrm{mg}$, niacin $12.0 \mathrm{mg}$, inositol $12.0 \mathrm{mg}$, and choline $400 \mathrm{mg}$ per $100 \mathrm{~g}$ of diet. 
Microradioautography of vitamin $E$ in adrenal gland. Adrenal glands removed from rats killed at various hours following injection were immediately frozen at $-70^{\circ} \mathrm{C}$ in acetone-dry ice. Then they were cut into $8 \mu \mathrm{m}$ microsections by AMES Cryostat Type II $\left(-20^{\circ} \mathrm{C} \sim-30^{\circ} \mathrm{C}\right)$. These sections were desiccated in a $\mathrm{P}_{2} \mathrm{O}_{5}$ chamber at room temperature over night, and then fixed with formalin vapors. After they were dipped in a two-fold dilute of emulsified NRM2 at $40^{\circ} \mathrm{C}$, they were exposed to tritium at $4^{\circ} \mathrm{C}$ for an adequate period of time. After exposure, the sections were developed and stained with hematoxylin and eosin.

Whole-body irradiation and TBA determination. The whole bodies of animals were irradiated in a perforated box of $14 \times 16 \times 4 \mathrm{~cm}$ at a dosage level of 100 Roentgens daily for eight days with Shimazu ST-2000 ${ }^{60}$ Co Irradiation Apparatus. Lipoperoxide formation in tissues and plasma was estimated in terms of TBA (thiobarbituric acid color reaction). TBA values of tissue were determined by a modification of Bieri-Anderson's method (Bieri and Anderson 1960) and those of plasma were determined according to Yagi-Ohama's method (Yagi et al. 1968). The absorbance at $535 \mathrm{~nm}$ was measured with a Hitachi 124 double beam spectrophotometer.

\section{Results}

\section{Tissue uptake of radioactive vitamin $E$}

The tissue uptake of radioactive liposoluble vitamin $\mathrm{E}$ was relatively slow and reached a peak at $24 \mathrm{hr}$ after administration. The adrenal uptake of vitamin $\mathrm{E}$ reached a peak at $24 \mathrm{hr}$ and its radioactivity per g wet tissue was approximately 10 times higher than that in other tissues. The uptake in mesenteric adipose

Fig. 1. Tissue uptake of $\mathrm{D}$ - $\alpha$-tocopherol in rat. Uptake activity is expressed as dpm per $\mathrm{g}$ wet tissue. Values represent the mean of three determinations of pooled tissues from two animals.

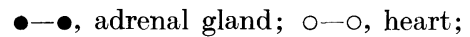
$\Delta-\Delta$, adipose tissue; $\Delta-\Delta$, pancreas; $\square-\mathbf{m}$, liver; $\square-\square$, spleen; $\times-\times$, muscle; $\square \cdot \square$, blood; $\Delta \cdot \Delta$, kidney; $\bullet$, brain.

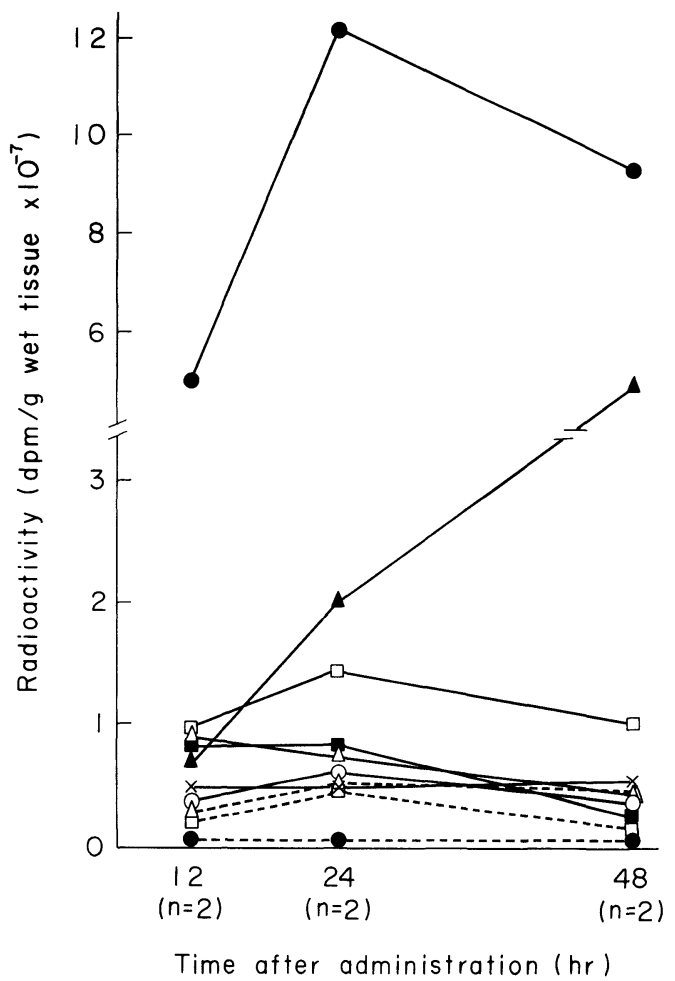


tissue gradually increased and rose to far higher levels at $48 \mathrm{hr}$. It is evident that the uptake of vitamin $\mathrm{E}$ administered was specifically high in the adrenal gland. Furthermore, high specific radioactivity was still detected in rat adrenal gland at $48 \mathrm{hr}$ (Fig. 1).

\section{Microradioautography of vitamin $E$ in adrenal gland}

Under adrenal microradioautographic observations, radioactive grains were found in the extracellular space of the whole adrenal cortex at $12 \mathrm{hr}$ after administration of radioactive vitamin $\mathrm{E}$, and they were not found in the adrenal medulla (data not shown). At 24 and $48 \mathrm{hr}$, however, the grains were clearly distributed in the cells of fascicular and reticular zones. A low radioactivity was also detected in the glomerular zone and adrenal medulla (Fig. 2). These results indicate that the intracellular localization of administered vitamin $\mathrm{E}$ was mainly in the fascicular and reticular zones of the adrenal cortex.

\section{Effect of whole-body irradiation on lipoperoxidation}

Twenty-three normal rats weighing 100 to $120 \mathrm{~g}$, which had been fed the control diet, were divided into two groups; irradiated and unirradiated. Thirteen rats were exposed to whole body irradiation in a total dose of $800 \mathrm{R}$ by ${ }^{60} \mathrm{Co}$, and four of them died during irradiation. Immediately after final irradiation the animals were killed by decapitation, and blood samples were collected. The adrenals were excised, cleaned, and weighed. The tissues were homogenized in $10 \mathrm{ml}$ of cold $0.1 \mathrm{M}$ phosphate buffer ( $\mathrm{pH}$ 7.4). The level of TBA from each homogenate and plasma was determined triplicately. The adrenal cortex of each irradiated animal was examined under an electron microscope.

A marked decrease in body weight of the irradiated was observed as compared with the unirradiated. However, there was no significant difference in adrenal weight between two groups. It is of interest to note that the adrenal TBA levels of the irradiated were significantly elevated and were about 2.2 times higher than those of the unirradiated controls. The plasma TBA levels of the irradiated were also significantly high, being 2.0 times as high as those of the unirradiated

TABLE 2. Effect of whole-body irradiation on TBA formation of the rat adrenal and plasma

$\begin{array}{lcc} & \begin{array}{c}\text { Irradiated group } \\ (n=8)\end{array} & \begin{array}{c}\text { Unirradiated group } \\ (n=10)\end{array} \\ \text { Body weight }(\mathrm{g}) & & \\ \text { Adrenal weight }(\mathrm{mg}) & 15.6 \pm 0.6 & 143.0 \pm 6.7 \\ \text { Adrenal TBA } & 1429.4 \pm 259.8^{*} & 15.0 \pm 0.7 \\ \text { Plasma TBA } & 26.8 \pm 3.5 \dagger & 13.6 \pm 1.3\end{array}$

Mean \pm s.e. TBA value is expressed as absorbance at $535 \mathrm{~nm}$ per g adrenal tissue $\left(\times 10^{-2}\right)$ and per $\mathrm{ml}$ of plasma $\left(\times 10^{-2}\right)$. $* p<0.05, \dagger p<0.005,+p<0.001$ : Significantly different from the unirradiated control by Student's $t$ test. 


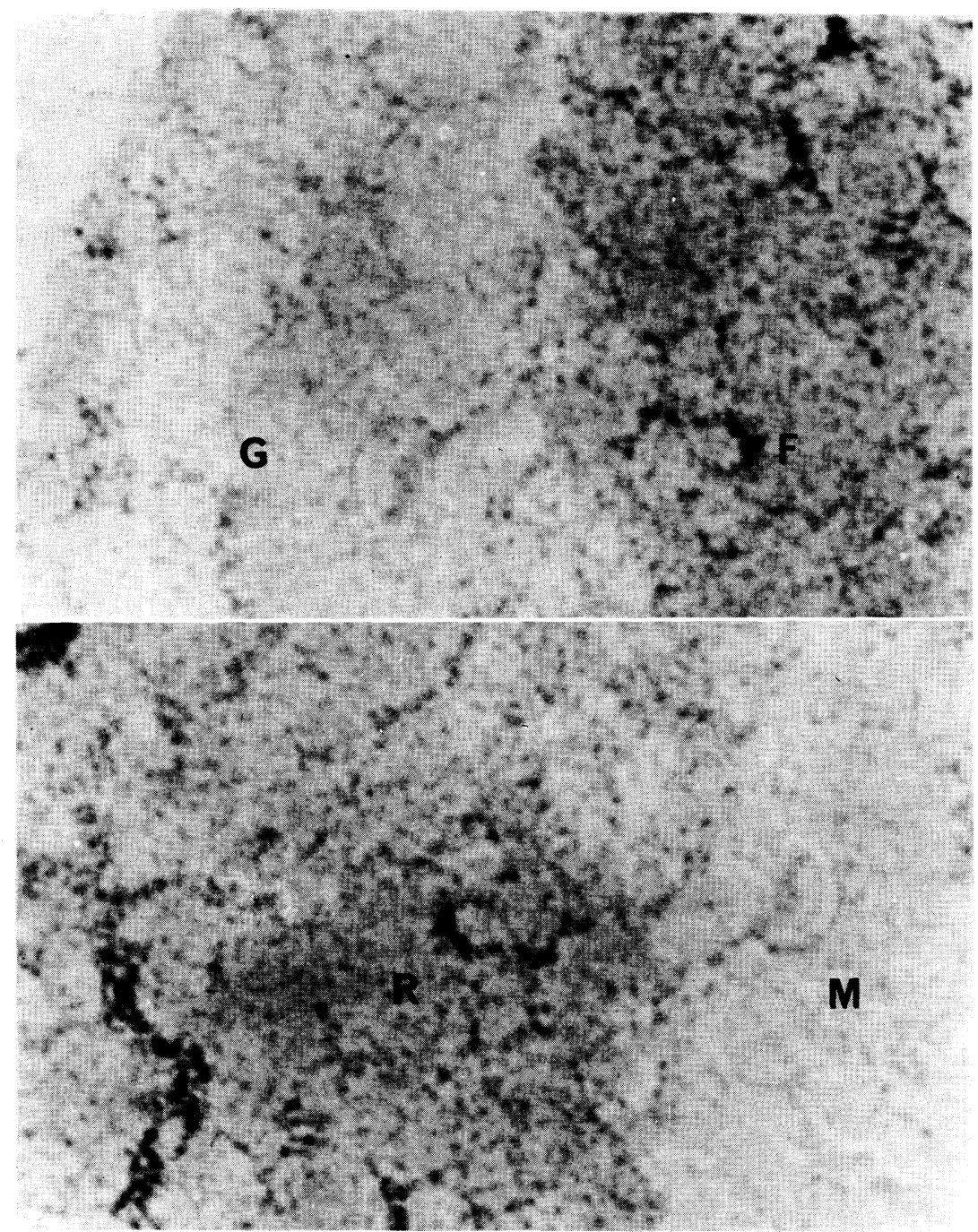

Fig. 2. Microradioautograph of the rat adrenal at $24 \mathrm{hr}$ following administration of radioactive tocopherol. H.E. stained. $\times 400$. F, fasciculata; G, glomerulosa; M, medulla; $R$, reticularis. Note numerous radioactive grains seen in the fascicular and reticular zones of the adrenal cortex. They are slightly intaken to the glomerular zone and adrenal medulla.

controls (Table 2). It was shown that whole body ${ }^{60} \mathrm{Co}$ irradiation could produce a significant increase in in vivo lipoperoxide formation.

The electron microscopic study of the irradiated rat adrenal cortex showed an increase in the number of lysosomes as compared with control and a high dense membranous structure, the so-called myelin figure, in lysosomes of the cells of fascicular and reticular zones (Fig. 3), where lipofuscin pigments also deposit along with aging. 


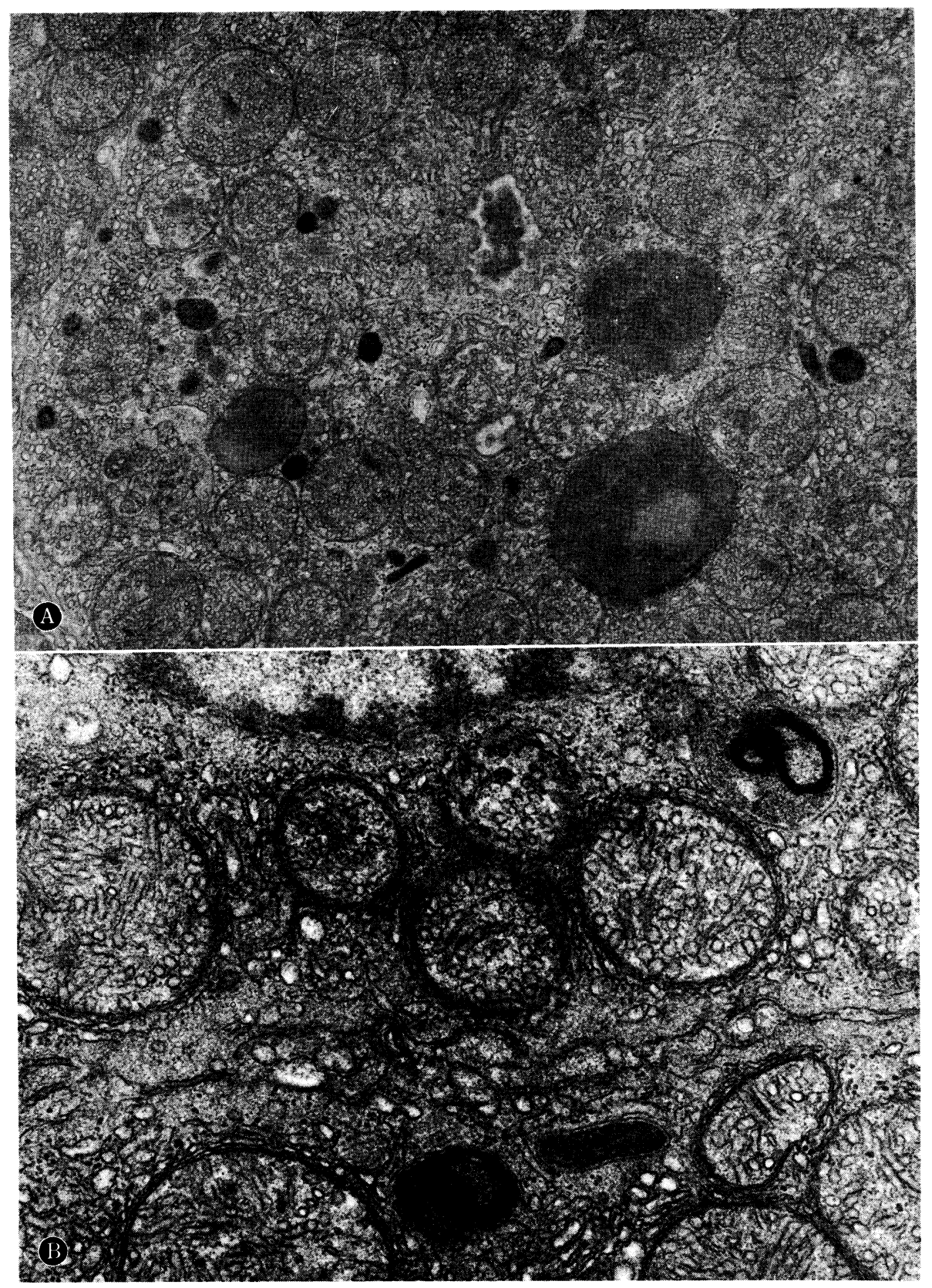

Fig. 3. Ultrastructural change of rat adrenocortical cells after $800 \mathrm{R}$ whole-body irradiation. A: Lysosomes have increased in the cells of the reticular zone. $\times 11,200$. B: Myelin figures have appeared in lysosomes of the cells of the fascicular and reticular zones. $\times 28,000$. 


\section{Inhibitory effect of tocopherol on lipoperoxidation}

Ten rats, weighing 100 to $120 \mathrm{~g}$, were divided into two groups; control diet group and vitamin $\mathrm{E}$ deficient diet group. After three months of feeding each group was further subdivided into the irradiated and the unirradiated. The animals were killed by decapitation, and the adrenal glands, testes, and livers were removed and weighed. These organs were homogenized in 10, 20, and $50 \mathrm{ml}$ of phosphate buffer respectively, and the TBA levels were immediately determined.

In comparison with the mean adrenal TBA level (261) of the unirradiated control diet group, that of the unirradiated vitamin $\mathrm{E}$ deficient rats was markedly higher, standing at 6,925. It is evident that adrenal lipoperoxide formation was increased in conditions of vitamin $\mathrm{E}$ deficiency. Whereas in the control diet group the mean adrenal TBA level of the irradiated group was 904, the actual adrenal TBA value of the irradiated animals in the vitamin $\mathrm{E}$ deficient group was markedly increased as high as 13,664 .

The TBA values of the testis and liver were found to be lower than that of the adrenal gland. With these tissues, the in vivo inhibitory effect of vitamin $\mathrm{E}$ on lipoperoxide formation in the irradiated and unirradiated rats showed a similar pattern as with the adrenal gland (Table 3).

TABLE 3. Inhibitory effect of tocopherol on TBA formation of the irradiated and unirradiated rats

Vitamin E deficient

$\begin{array}{lcc}\text { Organ } & \begin{array}{c}\text { Irradiated } \\ (\boldsymbol{n = 2})^{*}\end{array} & \begin{array}{c}\text { Unirradiated } \\ (\boldsymbol{n}=\mathbf{3})\end{array} \\ \text { Adrenal } & 13664 \pm 917 \uparrow & 6925 \pm 404 \\ \text { Testis } & 137 \pm 10 & 39 \pm 3 \\ \text { Liver } & 373 \pm 29 & 100 \pm 9\end{array}$

\section{Control}

$\begin{array}{cc}\begin{array}{c}\text { Irradiated } \\ (n=3)\end{array} & \begin{array}{c}\text { Unirradiated } \\ (\boldsymbol{n}=2)\end{array} \\ 904 \pm 88 & 261 \pm 20 \\ 22 \pm 2 & 11 \pm 1 \\ 99 \pm 8 & 61 \pm 5\end{array}$

* Number of animals. † TBA value is expressed as absorbance at $535 \mathrm{~nm}$ per $\mathrm{g}$ wet tissue $\left(\times 10^{-2}\right)$. Values represent the mean \pm s.E. of three TBA determinations of pooled tissue homogenates from each group.

\section{Discussion}

In our early study (Umeda 1978), we demonstrated that adrenal vitamin $\mathrm{E}$ content and lipoperoxide formation were high among the rat tissues. It was observed that this tissue contained a higher concentration of vitamin $\mathrm{E}$ than any other tissue and its TBA value was the highest second to that of the pituitary gland. In the present study of administered vitamin $\mathrm{E}$, it was also shown that the adrenal uptake of this vitamin was the highest in various tissues of rats (Fig. 1). Oswald et al. (1962) and Gloor et al. (1963) also reported a similar high uptake pattern in the rat adrenal gland. Our microradioautographic study showed that, after given intervals of time following administration, vitamin $\mathrm{E}$ accumulated in the adrenal cortical cells, notably in the fascicular and reticular zones (Fig. 2). 
According to the fluorescent microscopic observation of the adrenal cortices of rats and mice by William (1970), vitamin $\mathrm{E}$ was present mainly in the fascicular and reticular zones. These findings suggest that vitamin $\mathrm{E}$ as an antioxidant may play an important role in the control of adrenal lipoperoxide formation and subsequent lipofuscin deposition.

Thus far, quite a number of in vitro studies have been reported on the increase of lipoperoxide formation caused by x-ray irradiation (Horgan et al. 1957; Philpot and Roodyn 1959; Wyss et al. 1963). We could confirm the increase in TBA content in the blood, adrenal gland (Table 1), testis and liver (not shown in this report) in the present experiments of $800 \mathrm{R}{ }^{60} \mathrm{Co}$ whole-body irradiation in rats. In spite of the previous finding that adrenal glands are morphologically insensitive to x-ray (Warren 1943), a myelin figure in the lysosomes of ${ }^{60} \mathrm{Co}$-irradiated rat adrenal cortex was observed by electron microscopy (Fig. 3). It remains to be clarified whether this membranous structure results from the accumulation of subcellular membranes destroyed by peroxidation of polyunsaturated fatty acids in reticular and fascicular cells of the adrenal cortex, or whether it is formed as an intermediate product of lipoperoxide amendment in lysosome. It might also be intriguing to regard this structure as a short-term incomplete form of lipofuscin. Incidentally, Molenaar et al. (1970) found a similar structure in the cells of intestinal mucosa of vitamin $\mathrm{E}$ deficient animals.

Generally speaking, lipoperoxide is formed in vivo by two different mechanisms; one is nonenzymatic and chemical peroxidation by free radical initiators (Tappel 1955; Mcknight et al. 1956), and the other is oxidation by microsomal enzyme NADPH (Siekevitz 1956; Hochstein and Ernster 1963). Motohashi and Ohsawa (1968) demonstrated that, in the guinea pig adrenal gland TBA levels rose with aging. In addition, our whole-body irradiation as an aging model led to the elevation of lipoperoxide in rat adrenal.

As shown in Table 3, it was demonstrated that vitamin E exerts an inhibitory effect on nonenzymatic and/or enzymatic lipoperoxidation in the rat adrenal gland.

Therefore, it is suggested that vitamin E can be regarded as a useful preventive agent against adrenal lipoperoxide formation and adrenal aging.

\section{Acknowledgments}

We wish to thank Prof. H. Yoshinaga, Department of Experimental Radiology, Faculty of Medicine, Kyushu University, for his valuable advice and permission to use the ${ }^{60} \mathrm{Co}$ irradiation apparatus. This investigation was supported in part by Grant-in-Aid No. 948180 from the Ministry of Education, Science and Culture, Japan. In addition, we greatly appreciate Eisai Co. for the supply of the experimental animals and materials.

\section{References}

1) Bieri, J.G. \& Anderson, A.A. (1960) Peroxidation of lipids in tissue homogenates as related to vitamin E. Arch. Biochem. Biophys., 90, 105-110.

2) Einarson, L. \& Ringsted, A. (1938) Effect of Chronic Vitamin E Deficiency on the Nervous System and Skeletal Musculature in Adult Rats.

Levin \& Munksgaard, Copenhagen, pp. 1-163. 
3) Gloor, U., Weber, F., Wursch, J. \& Oswald, W. (1963) Verteilung der Radioak-

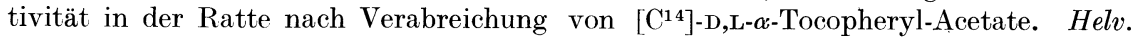
chim. Acta, XI VI, Fusciculus VI, 2457-2460.

4) Harman, D. (1956) Aging: A theory based on free radical and radiation chemistry. J. Gerontol., 11, 298-300.

5) Hirai, S. \& Yoshikawa, M. (1970) Vitam in E and aging of the nervous system. In: International Symposium on Vitamin E, Hakone, Japan, edited by N. Shimazono \& Y. Takagi, Kyoritsu Shuppan, Tokyo, pp. 228-237.

6) Hochstein, P. \& Ernster, L. (1963) ADP-activated lipid peroxidation coupled to the TPNH oxidase system of microsomes. Biochem. biophys. Res. Commun., 12, 388-410.

7) Horgan, V.J., Philpot, J. St. L., Porter, B.W. \& Roodyn, D.B. (1957) Toxicity of autoxidized squalene and linoleic acid, and of simpler peroxides, in relation to toxicity of radiation. Biochem. J., 67, 551-558.

8) Masugi, F. \& Nakamura, T. (1976) Effect of vitamin E deficiency on the level of superoxide dismutase, glutathion peroxidase, catalase and lipid peroxide in rat liver. Int. J. Vit. Nutr. Res., 46, 187-191 .

9) Mcknight, R.C., Hunter, F.E. \& Oehlert, W.H. (1956) Mitochondrial membrane ghosts produced by lipid peroxidation induced by ferrous ion. I. Production and general morphology. J. biol. Chem., 240, 3439-3446.

10) Molenaar, I., Vos, J., Jager, F.C. \& Hommes, F.A. (1970) The effect of vitamin E deficiency on the ultrastructure of intestinal epithelial cells and their membranes in particular. In: International Symposium on Vitamin E, Hakone, Japan, edited by N. Shimazono \& Y. Takagi, Kyoritsu Shuppan, Tokyo, pp. 76-101.

11) Motohashi, K. \& Ohsawa, N. (1968) Aging in organ function and metabolism. 4. Adrenal gland. Jap. J. Geriat., 5, 55-59.

12) Oswald, W., Raymond, H.B. \& Gloor, U. (1962) Absorption and distribution of vitamin $\mathrm{E}$ in the tissues. Vitamins and Hormones, 20, 441-445.

13) Philpot, J. St. L. \& Roodyn, D.B. (1959) A comparison between the effects in mice of injected organic peroxides and of whole-body $\mathrm{x}$ irradiation. Int. J. Rad. Biol., 1, $372-382$.

14) Siekevitz, P. (1956) Origin and functional nature of microsomes. Fed. Proc., 24, 11531155 .

15) Tappel, A.L. (1955) Unsaturated lipid oxidation catalyzed by hematin compounds. J. biol. Chem., 217, 721-733.

16) Tappel, A.L. (1962) Vitamin E as the biological lipid antioxidant. Vitamins and Hormones, 20, 493-510.

17) Tappel, A.L. (1968) Will antioxidant nutrients slow aging process ? Geriatrics, 23, 97-105.

18) Tappel, A.L., Brain, F. \& David, D. (1973) Effect of antioxidants and nutrients on lipid peroxidation fluorescent products and aging parameters in the mouse. $J$. Gerontol., 28, 415-424.

19) Umeda, F. (1978) Functional and morphological studies on pituitary-gonadal and adrenal axes in vitamin $\mathrm{E}$ deficient and supplemented male rats. Fukuoka Acta medica, 69, 327-338.

20) Warren, S. (1943) Effects of radiation on normal tissues. Arch. Path., 35, 304-353.

21) William, R. (1970) Lipid pigment formation as a function of age, disease, and vitamin E deficiency. In: International Symposium on Vitamin E, Hakone, Japan, edited by N. Shimazono \& Y. Takagi, Kyoritsu Shuppan, Tokyo, pp. 207-227.

22) Wyss, O., Wiesen, C., Scheiberger, G.E. \& Roodyn, D.B. (1963) Peroxides and mutations. Rad. Res., Suppl. 3, 184-191.

23) Yagi, K., Nishigaki, I. \& Ohama, H. (1968) Measurement of serum TBA-values. Vitamin, 37, 105-112. (Japanese)

24) Zalkin, H. \& Tappel, A.L. (1960) Studies on the mechanism of vitamin E action. IV. Lipid peroxidation in the vitamin E-deficient rabbit. Arch. Biochem. Biophys., 88, 113-117. 